Published in final edited form as:

Front Biosci. ; 14: 150-158.

\title{
The role of platelets in acute lung injury (ALI)
}

\author{
Alexander Zarbock ${ }^{1,2}$ and Klaus Ley ${ }^{1,3}$ \\ ${ }^{1}$ Robert M. Berne Cardiovascular Research Center, University of Virginia, Charlottesville, Virginia, \\ USA \\ ${ }^{2}$ Department of Anesthesiology and Intensive Care Medicine, University of Münster, Münster, \\ Germany \\ ${ }^{3}$ Departments of Biomedical Engineering, Molecular Physiology and Biological Physics, University \\ of Virginia, Charlottesville, Virginia, USA
}

\begin{abstract}
Acute lung injury (ALI) is a common syndrome associated with a high mortality rate. Better understanding of the pathophysiology of acute lung injury and progress in supportive care and mechanical ventilation have led to slightly improved clinical outcomes. New evidence shows that the interplay between platelets, leukocytes and endothelial cells is critical in the pathogenesis of ALI. Key molecules involved in this interaction include P-selectin (Selp) and the eicosanoid thromboxane $\mathrm{A}_{2}\left(\mathrm{TXA}_{2}\right)$, suggesting potential new targets for pharmacological intervention. In this review, we summarize the aspects of the interactions between platelets, leukocytes, and endothelial cells that are relevant for the pathogenesis of ALI.
\end{abstract}

\section{Keywords}

acute lung injury; platelets; leukocytes

\section{Introduction}

\subsection{Definition, Epidemiology}

Acute lung injury (ALI) is a common, devastating syndrome that affects surgical as well as medical patients. The syndrome is defined as an acute hypoxemic respiratory failure with bilateral pulmonary infiltrates that are not caused by left atrial hypertension (1). This new definition of the ALI has the advantage of identifying patients at an early stage of the syndrome, but it does not consider the underlying cause of ALI or other affected organ systems that can influence the outcome. A recent study showed that the overall incidence of acute lung injury is 78.9 per 100,000 person-years in the United States (2). However, the incidence is age-dependent and increases from 16 per 100,000 person-years for those 15 through 19 years of age to 306 per 100,000 for those 75 through 84 years of age (2). Despite improved treatment, the disease is associated with a high mortality of up to $38 \%$. Based on these data, 190,600 cases of ALI occur every year in the United States and cause 3.8 million hospital days (2), which places a significant burden on the heath care system.

Corresponding author Klaus Ley, M.D., University of Virginia Health System, Cardiovascular Research Center, P.O. Box 801394, Charlottesville, VA 22908-1394, USA, Phone: +1 (434) 243-9966, Fax: +1 (434) 924-2828, E-mail: klausley @ virginia.edu, after November $1^{\text {st. }}$ La Jolla Institute for Allergy \& Immunology, 9420 Athena Circle Drive, La Jolla, CA 92037, USA, Phone: +1 (858) 752-6661, Fax: +1 (858) 752-6985, E-mail: klaus@liai.org. 


\subsection{Pathogenesis}

The underlying causes of ALI can be divided into those associated with direct injury of the lung, including trauma, pneumonia, aspiration of gastric content, inhalational injury, reperfusion-induced pulmonary edema, and those that are caused indirectly in the context of systemic processes like sepsis, severe trauma with shock or multiple transfusions. The risk of developing ALI substantially increases in the presence of multiple predisposing disorders (3), including chronic lung diseases (4).

During the acute phase of ALI, the alveolar-capillary barrier, composed of vascular endothelium, a narrow interstitial space and alveolar epithelium, is damaged (Figure 1). This causes an increase of vascular and epithelial permeability with influx of protein-rich fluid into the interstitial and alveolar compartments (5), causing impaired gas exchange. This phase is characterized by neutrophil, macrophage, and erythrocyte infiltration and the formation of hyaline membranes (6). The damage of the epithelial integrity is of critical importance in ALI, as this barrier regulates permeability (7). Fluid transport is also regulated by the alveolar epithelium $(8,9)$, which is also involved in surfactant production $(10)$. The reduced surfactant production caused by injury to alveolar type II pneumocytes leads to the formation of atelectasis (6).

ALI induces the production and release of a myriad of cytokines and other pro-inflammatory mediators. These mediators can initiate and amplify the inflammatory response in ALI. Cytokines can be produced locally in the lung by alveolar macrophages, epithelial cells, fibroblasts, endothelial cells as well as by extrapulmonary cells like leukocytes. The chemokine receptor CXCR2 is critically involved in the pathogenesis of different models of ALI (11-14). This chemokine receptor binds the chemokine CXCL1, 2, 3, 5, 6, 7, and 8 in humans and CXCL1, 2, 3, 5, 6, and 7 in mice. The receptor is involved in regulation of vascular permeability and neutrophil recruitment in different models of ALI (11-14). Other chemokines and pro-inflammatory mediators like CCL2 (Monocyte Chemotactic Protein (MCP)-1) (15), cytosolic phospholipase A2 (cPLA2) (16), and platelet-activating factor (17) are also involved in regulating leukocyte recruitment and vascular permeability in the lung.

New evidence demonstrates that activated coagulation and impaired fibrinolysis are associated with ALI (18). During ALI, the coagulation system is activated, producing fibrin deposition in the lung $(19,20)$. Tissue factor (TF) released by activated monocytes binds coagulation factor VII, activates it to VIIa, which in turn converts X to its activated form Xa. This complex can produce thrombin and activate protease-activated recepotrs (PARs) on endothelial cells, inducing an inflammatory response with up-regulation of cytokines as well as thrombin formation. Thrombin also activates platelets by binding to platelet PAR1 and 4 (21). Thrombin also induces the conversion of fibrinogen to fibrin that, together with activated platelets, can induce the formation of microvascular thrombosis. The blockade of TF by a monoclonal antibody or a site-inactivated factor VIIa in the context of an E.coliinduced sepsis reduced systemic inflammation, improved gas exchange and lung compliance, prevented fibrinogen depletion, and mitigated lung injury $(22,23)$. Lungprotective ventilation, which is associated with diminished release of pro-inflammatory mediators (24), also leads to reduced activation of the coagulation cascade (25).

Previous studies showed that modulating the coagulation system by protein $\mathrm{C}$ can be beneficial in ALI (26). In a clinical study with patients suffering from septic and non-septic ALI, lower plasma protein C levels and higher levels of thrombomodulin in the bronchoalveolar lavage are associated with worse clinical outcomes, including death, fewer ventilator-free days, and more nonpulmonary organ failures (26). The alveolar epithelium expresses thrombomudulin and endothelial protein $\mathrm{C}$ receptor (EPCR), which may limit alveolar fibrin deposition (27). 


\subsection{Leukocyte Recruitment into the lung}

Neutrophil influx is a hallmark of ALI. Several clinical and experimental studies have demonstrated the importance of neutrophil-mediated injury during the development of ALI (28), but the exact recruitment mechanisms remain to be fully determined. Leukocyte recruitment in the systemic circulation proceeds in a multi-step cascade and is well established $(29,30)$, whereas the recruitment of leukocytes into the lung is influenced by complex processes including the unique capillary structure of the lung, neutrophil deformability, and adhesion molecules (31). Due to the relation of the size of pulmonary capillaries (diameter 2-15 $\mu \mathrm{m}$ ) (32) to the size of neutrophils, neutrophils have to stop several times and change their shape in order to penetrate the pulmonary capillaries. This leads to a significantly prolonged transit time compared to erythrocytes and a 40- to 100fold neutrophil accumulation ('marginated pool') in the lungs (33).

In response to inflammatory stimuli, pro-inflammatory mediators are released that are able to activate neutrophils and change their biomechanical properties by promoting polymerization of subcortical actin with a subsequent sequestration of stiff neutrophils in the pulmonary microvasculature $(34,35)$. The role of adhesion molecules in the sequestration step is not fully understood. It has been shown that L-selectin, which is expressed on leukocytes, is required for the sequestration of neutrophils in the lung in response to the formyl peptide fMLP, but not C5a, as shown by using blocking antibodies and L-selectindeficient mice (36). Blocking E-selectin and L-selectin by antibodies did not influence neutrophil sequestration in a model of sepsis-induced ALI (37).

The pulmonary capillary vasculature is the location of neutrophil migration. Neutrophils can migrate through the endothelium by penetrating interendothelial junctions or using a transcellular route (38). The interactions between neutrophils and vascular endothelium as well as the release of pro-inflammatory mediators by neutrophils induce cytoskeletal changes in the endothelial cells. Cell-cell-interactions lead to intracellular signaling through transmembrane proteins in the area of interendothelial junctions (e.g. platelet endothelial cell adhesion molecule (PECAM)-1, CD99) and this might trigger transient remodeling of the junction (39-41).

Dependent on the stimulus, neutrophil recruitment into the lung can be dependent on or independent of $\beta_{2}$ integrins (CD18) (31). $\beta_{2}$ integrins include Lymphocyte Function Antigen (LFA-1, $\alpha_{L} \beta_{2}$, CD11a/CD18), (Mac-1, $\left.\alpha_{M} \beta_{2}, C D 11 b / C D 18\right), p 150,95$ (CD11c/CD18), and $a_{d} \beta_{2}$ integrin (CD11d/CD18) (42). The CD18-dependent neutrophil migration pathway uses endothelial ICAM-1 as a counter-ligand. Both Mac-1 (43) and LFA-1 (44) appear to be very important in neutrophil recruitment into the lung in models of LPS-induced pulmonary inflammation.

\section{Platelets}

Platelets play a central role in hemostasis, wound healing, and inflammation. They originate form bone marrow megakaryocytes and contain glycogen, mitochondria, and at least three types of granules (dense core granules, lysosomes, and a-granules). The granules contain adhesion molecules, factors relevant for coagulation and fibrinolysis, calcium, and pyrophosphate (45). Platelets circulating in the blood are in a quiescent state. Following activation, platelets can secrete the content of the granules, change their shape, and upregulate the expression of adhesion molecules including P-selectin, PECAM-1 (CD31), glycoprotein (GP) IIb/IIIa (aIIb $\beta 3$ ) integrin, fibronectin, and thrombospondin (46). 


\subsection{Platelet-Leukocyte-Endothelium Interaction}

Platelets can adhere to von-Willebrand Factor (vWF) expressed on activated endothelial cells or in the subendothelial space (47). This interaction is mediated by the glycoprotein (GP)Ib/IX/V complex on platelets. This complex is constitutively expressed on platelets and consists of four gene products (GPIba, GPIb $\beta$, GPIX, and GPV). Binding of the GPIb/IX/V complex to vWF initiates the activation of the integrin $\alpha_{I I b} \beta_{3}$ on platelets via "outside-in" signaling (48-51), resulting in contraction, shape change, spreading, secretion and aggregation (52-54). GPIba is also a low affinity-ligand for P-selectin (55). Since the density of GPIba on the platelet membrane is very high, GPIba can mediate P-selectindependent rolling on activated endothelium (55) and platelet-platelet-interactions (56).

GPIIb/IIIa ( $\alpha_{\text {IIb }} \beta_{3}$ integrin) is an important adhesion molecule on platelets, responsible for mediating platelet aggregation and some platelet-neutrophil-interactions. In the resting state, $\alpha_{I I b} \beta_{3}$ is able to bind immobilized but not soluble fibrin(ogen) (57). Outside-in signaling through G-protein coupled receptors leads to conformational changes of $\mathrm{a}_{\mathrm{IIb}} \beta_{3}$ and subsequent binding of ligands including fibronectin, fibrinogen, vitronectin, vWF, and thrombospondin (TSP)-1 (58). Like other integrins, $\alpha_{\text {IIb }} \beta_{3}$ is also able to mediate "outsidein" signaling and regulate activation of platelets. Following the initial contact between platelets and endothelium and activation of the integrin, it can bind soluble vWF, fibrinogen, and other ligands. Another integrin on platelets, $\alpha_{5} \beta_{1}$, can bind fibronectin and induce stable adhesion (59). Under low shear conditions, integrins alone can mediate platelet adhesion (60), but GPIb/IX/V interaction with vWF is required for adhesion under high shear.

P-selectin, a type I membrane protein, is stored in a-granules of platelets and in WeibelPalade bodies of endothelial cells and is rapidly brought to the cell surface following activation. P-selectin mediates the initial binding ('capturing') of platelets to leukocytes and leukocytes to endothelial cells. Platelet P-selectin can bind to P-selectin glycoprotein ligand (PSGL)-1 (61-63) and perhaps a second ligand (64) on different subsets of leukocytes. Following the initial capturing, firm neutrophil-platelet adhesion is mediated by binding of the leukocyte integrin $a_{M} \beta_{2}(C D 11 b, M a c-1)(65,66)$ to GPIb on platelets (67). In addition, fibrinogen bound to platelet $\alpha_{v} \beta_{3}$ or $\alpha_{I I b} \beta_{3}$ can form a bridge to leukocyte Mac-1 (68). Alternatively, Intercellular Adhesion Molecule (ICAM)-2 on platelets and $\alpha_{L} \beta_{2}$ on neutrophils can induce firm adhesion (69).

Following the adhesion of neutrophils to platelets, neutrophils are activated through PSGL-1 (62, 70, 71), the Triggering Receptor Expressed on Myeloid cells (TREM)-1 (72), lipid mediators and chemokines presented by platelets $(68,73)$, and integrin mediated "outsidein" signaling (74). Platelet depletion reduces neutrophil rolling and adhesion in various animal models of inflammation $(75,76)$.

\subsection{Platelets in ALI}

Platelets are involved in different inflammatory lung diseases $(77,78)$. Growing evidence suggests that platelets also play a crucial role in the pathogenesis of acute lung injury (79-81), but the exact mechanisms by which platelets contribute to tissue damage and influence neutrophil recruitment are still unknown.

Intrapulmonary causes of ALI, like acid aspiration and pneumonia, activate the lung microvascular endothelium, and this consecutively leads to up-regulation of adhesion molecules including ICAM-1 (44), release and presentation of chemokines (82) and lipid mediators (79). Systemic inflammatory stimuli can also induce an up-regulation of adhesion molecules on lung microvascular endothelium (80) and mediate neutrophil accumulation (83) that requires TLR4. During endotoxemia, platelets roll along and firmly adhere to lung capillary endothelial cells as shown by intravital microscopy (81). This interaction is mainly 
mediated by platelet P-selectin and an unknown counter-receptor on the endothelium (81). Platelets that adhere to the endothelium can become fully activated by G-protein coupled receptors (84) and integrin outside-in signaling (85), subsequently releasing chemokines and lipid mediators (79). These can either activate attached leukocytes or induce further activation of endothelial cells by releasing pro-inflammatory mediators (79). Platelet activation is associated with an up-regulation of P-selectin expression (84), which mediates 'secondary capturing' of neutrophils to the vessel wall. 'Secondary capture' is the interaction of a freely flowing leukocyte with an adherent leukocyte or platelet, leading to subsequent attachment to the endothelium and rolling. Elimination or blockade of P-selectin reduces neutrophil recruitment into the lung (79) and rescues mice from acid-induced ALI.

Although, the interaction between platelets and neutrophils is mediated by several molecules, it is sufficient to block or eliminate platelet P-selectin to reduce the number of platelet-neutrophil aggregates during ALI (79). The physical interaction between these two cell types (Figure 2) leads to a reciprocal activation by activating G-protein-coupled receptors and integrin outside-in signaling (74). Due to the mechanical retention of circulating neutrophils in the narrow segments of the alveolar capillaries, it might be possible that integrin activation and binding to their ligands is sufficient for neutrophil recruitment. The pro-inflammatory mediator, thromboxane $\mathrm{A}_{2}\left(\mathrm{TXA}_{2}\right)$ was identified as an important mediator released by platelet-neutrophil aggregates in ALI (79). TXA 2 acts on endothelial cells and induces the expression of adhesion molecules, polymerization of actin, and contraction (79). However, it is likely that other lipid mediators and chemokines released from activated platelets contribute to ALI.

\section{Conclusions and further directions}

In summary, these findings from animal studies indicate that platelets may be major pathogenic contributors in inflammatory lung diseases and ALI induced by sepsis, aspiration of gastric content, pneumonia, or ventilator-induced lung injury. The precise mechanisms of the role of platelets for neutrophil recruitment into the inflamed lung and the release of proinflammatory mediators in ALI remain to be elucidated. Inhibition of platelets and/or platelet-neutrophil-interactions could present a very powerful and promising target in the treatment of ALI. However, further clinical trials must distinguish between infectious and non-infectious ALI, because neutrophils play a critical role in host defense. While inhibition of neutrophil recruitment may be beneficial in the abacterial phase of ALI (86), such as in aspiration-induced ALI, it could be devastating in patients with bacterial ALI.

\section{Acknowledgments}

The authors wish to thank Jan Redick, Advanced Microscopy Facility, University of Virginia, for her excellent technical assistance with transmission electron microscopy. A.Z. is supported by a grant of the Deutsche Forschungsgemeinschaft (DFG AZ 428/2-1). The original work from K.L.'s lab is supported by the National Institutes of Health (HL73361).

\section{References}

1. Bernard GR, Artigas A, Brigham KL, Carlet J, Falke K, Hudson L, Lamy M, Legall JR, Morris A, Spragg R. The American-European Consensus Conference on ARDS. Definitions, mechanisms, relevant outcomes, and clinical trial coordination. Am J Respir Crit Care Med. 1994; 149:818-824. [PubMed: 7509706]

2. Rubenfeld GD, Caldwell E, Peabody E, Weaver J, Martin DP, Neff M, Stern EJ, Hudson LD. Incidence and outcomes of acute lung injury. N Engl J Med. 2005; 353:1685-1693. [PubMed: 16236739] 
3. Pepe PE, Potkin RT, Reus DH, Hudson LD, Carrico CJ. Clinical predictors of the adult respiratory distress syndrome. Am J Surg. 1982; 144:124-130. [PubMed: 7091520]

4. Hudson LD, Milberg JA, Anardi D, Maunder RJ. Clinical risks for development of the acute respiratory distress syndrome. Am J Respir Crit Care Med. 1995; 151:293-301. [PubMed: 7842182]

5. Pugin J, Verghese G, Widmer MC, Matthay MA. The alveolar space is the site of intense inflammatory and profibrotic reactions in the early phase of acute respiratory distress syndrome. Crit Care Med. 1999; 27:304-312. [PubMed: 10075054]

6. Ware LB, Matthay MA. The acute respiratory distress syndrome. N Engl J Med. 2000; 342:13341349. [PubMed: 10793167]

7. Wiener-Kronish JP, Albertine KH, Matthay MA. Differential responses of the endothelial and epithelial barriers of the lung in sheep to Escherichia coli endotoxin. J Clin Invest. 1991; 88:864875. [PubMed: 1885774]

8. Modelska K, Pittet JF, Folkesson HG, Courtney Broaddus V, Matthay MA. Acid-induced lung injury. Protective effect of anti-interleukin- 8 pretreatment on alveolar epithelial barrier function in rabbits. Am J Respir Crit Care Med. 1999; 160:1450-1456. [PubMed: 10556104]

9. Sznajder JI. Strategies to increase alveolar epithelial fluid removal in the injured lung. Am J Respir Crit Care Med. 1999; 160:1441-1442. [PubMed: 10556102]

10. Greene KE, Wright JR, Steinberg KP, Ruzinski JT, Caldwell E, Wong WB, Hull W, Whitsett JA, Akino T, Kuroki Y, et al. Serial changes in surfactant-associated proteins in lung and serum before and after onset of ARDS. Am J Respir Crit Care Med. 1999; 160:1843-1850. [PubMed: 10588595]

11. Sue RD, Belperio JA, Burdick MD, Murray LA, Xue YY, Dy MC, Kwon JJ, Keane MP, Strieter RM. CXCR2 is critical to hyperoxia-induced lung injury. J Immunol. 2004; 172:3860-3868. [PubMed: 15004193]

12. Belperio JA, Keane MP, Burdick MD, Londhe V, Xue YY, Li K, Phillips RJ, Strieter RM. Critical role for CXCR2 and CXCR2 ligands during the pathogenesis of ventilator-induced lung injury. $\mathrm{J}$ Clin Invest. 2002; 110:1703-1716. [PubMed: 12464676]

13. Reutershan J, Morris MA, Burcin TL, Smith DF, Chang D, Saprito MS, Ley K. Critical role of endothelial CXCR2 in LPS-induced neutrophil migration into the lung. J Clin Invest. 2006; 116:695-702. [PubMed: 16485040]

14. Folkesson HG, Matthay MA, Hebert CA, Broaddus VC. Acid aspiration-induced lung injury in rabbits is mediated by interleukin-8-dependent mechanisms. J Clin Invest. 1995; 96:107-116. [PubMed: 7615779]

15. Maus U, von Grote K, Kuziel WA, Mack M, Miller EJ, Cihak J, Stangassinger M, Maus R, Schlondorff D, Seeger W, et al. The role of CC chemokine receptor 2 in alveolar monocyte and neutrophil immigration in intact mice. Am J Respir Crit Care Med. 2002; 166:268-273. [PubMed: 12153956]

16. Nagase T, Uozumi N, Ishii S, Kume K, Izumi T, Ouchi Y, Shimizu T. Acute lung injury by sepsis and acid aspiration: a key role for cytosolic phospholipase A2. Nat Immunol. 2000; 1:42-46. [PubMed: 10881173]

17. Nagase T, Ishii S, Kume K, Uozumi N, Izumi T, Ouchi Y, Shimizu T. Platelet-activating factor mediates acid-induced lung injury in genetically engineered mice. J Clin Invest. 1999; 104:10711076. [PubMed: 10525045]

18. Ware LB, Camerer E, Welty-Wolf K, Schultz MJ, Matthay MA. Bench to bedside: targeting coagulation and fibrinolysis in acute lung injury. Am J Physiol Lung Cell Mol Physiol. 2006; 291:L307-311. [PubMed: 16648240]

19. Idell S. Extravascular coagulation and fibrin deposition in acute lung injury. New Horiz. 1994; 2:566-574. [PubMed: 7804805]

20. Idell S, James KK, Levin EG, Schwartz BS, Manchanda N, Maunder RJ, Martin TR, McLarty J, Fair DS. Local abnormalities in coagulation and fibrinolytic pathways predispose to alveolar fibrin deposition in the adult respiratory distress syndrome. J Clin Invest. 1989; 84:695-705. [PubMed: 2788176]

21. Coughlin SR. Protease-activated receptors in hemostasis, thrombosis and vascular biology. J Thromb Haemost. 2005; 3:1800-1814. [PubMed: 16102047] 
22. Carraway MS, Welty-Wolf KE, Miller DL, Ortel TL, Idell S, Ghio AJ, Petersen LC, Piantadosi CA. Blockade of tissue factor: treatment for organ injury in established sepsis. Am J Respir Crit Care Med. 2003; 167:1200-1209. [PubMed: 12714343]

23. Welty-Wolf KE, Carraway MS, Ortel TL, Ghio AJ, Idell S, Egan J, Zhu X, Jiao JA, Wong HC, Piantadosi CA. Blockade of tissue factor-factor X binding attenuates sepsis-induced respiratory and renal failure. Am J Physiol Lung Cell Mol Physiol. 2006; 290:L21-31. [PubMed: 16100288]

24. Parsons PE, Eisner MD, Thompson BT, Matthay MA, Ancukiewicz M, Bernard GR, Wheeler AP. Lower tidal volume ventilation and plasma cytokine markers of inflammation in patients with acute lung injury. Crit Care Med. 2005; 33:1-6. discussion 230-232. [PubMed: 15644641]

25. Choi G, Wolthuis EK, Bresser P, Levi M, van der Poll T, Dzoljic M, Vroom MB, Schultz MJ. Mechanical ventilation with lower tidal volumes and positive end-expiratory pressure prevents alveolar coagulation in patients without lung injury. Anesthesiology. 2006; 105:689-695. [PubMed: 17006066]

26. Ware LB, Fang X, Matthay MA. Protein C and thrombomodulin in human acute lung injury. Am J Physiol Lung Cell Mol Physiol. 2003; 285:L514-521. [PubMed: 12754194]

27. Wang L, Bastarache JA, Wickersham N, Fang X, Matthay MA, Ware LB. Novel role of the human alveolar epithelium in regulating intra-alveolar coagulation. Am J Respir Cell Mol Biol. 2007; 36:497-503. [PubMed: 17099142]

28. Abraham E. Neutrophils and acute lung injury. Crit Care Med. 2003; 31:S195-199. [PubMed: 12682440]

29. Springer TA. Traffic signals on endothelium for lymphocyte recirculation and leukocyte emigration. Annu Rev Physiol. 1995; 57:827-872. [PubMed: 7778885]

30. Ley K, Laudanna C, Cybulsky MI, Nourshargh S. Getting to the site of inflammation: the leukocyte adhesion cascade updated. Nat Rev Immunol. 2007; 7:678-689. [PubMed: 17717539]

31. Doerschuk CM. Mechanisms of leukocyte sequestration in inflamed lungs. Microcirculation. 2001; 8:71-88. [PubMed: 11379793]

32. Doerschuk CM, Beyers N, Coxson HO, Wiggs B, Hogg JC. Comparison of neutrophil and capillary diameters and their relation to neutrophil sequestration in the lung. J Appl Physiol. 1993; 74:3040-3045. [PubMed: 8366005]

33. Doerschuk CM, Allard MF, Martin BA, MacKenzie A, Autor AP, Hogg JC. Marginated pool of neutrophils in rabbit lungs. J Appl Physiol. 1987; 63:1806-1815. [PubMed: 3693216]

34. Worthen GS, Schwab B 3rd, Elson EL, Downey GP. Mechanics of stimulated neutrophils: cell stiffening induces retention in capillaries. Science. 1989; 245:183-186. [PubMed: 2749255]

35. Drost EM, MacNee W. Potential role of IL-8, platelet-activating factor and TNF-alpha in the sequestration of neutrophils in the lung: effects on neutrophil deformability, adhesion receptor expression, and chemotaxis. Eur J Immunol. 2002; 32:393-403. [PubMed: 11813158]

36. Olson TS, Singbartl K, Ley K. L-selectin is required for fMLP- but not C5a-induced margination of neutrophils in pulmonary circulation. Am J Physiol Regul Integr Comp Physiol. 2002; 282:R1245-1252. [PubMed: 11893631]

37. Carraway MS, Welty-Wolf KE, Kantrow SP, Huang YC, Simonson SG, Que LG, Kishimoto TK, Piantadosi CA. Antibody to E- and L-selectin does not prevent lung injury or mortality in septic baboons. Am J Respir Crit Care Med. 1998; 157:938-949. [PubMed: 9517615]

38. Burns AR, Smith CW, Walker DC. Unique structural features that influence neutrophil emigration into the lung. Physiol Rev. 2003; 83:309-336. [PubMed: 12663861]

39. Shaw SK, Perkins BN, Lim YC, Liu Y, Nusrat A, Schnell FJ, Parkos CA, Luscinskas FW. Reduced expression of junctional adhesion molecule and platelet/endothelial cell adhesion molecule-1 (CD31) at human vascular endothelial junctions by cytokines tumor necrosis factoralpha plus interferon-gamma Does not reduce leukocyte transmigration under flow. Am J Pathol. 2001; 159:2281-2291. [PubMed: 11733377]

40. Su WH, Chen HI, Jen CJ. Differential movements of VE-cadherin and PECAM-1 during transmigration of polymorphonuclear leukocytes through human umbilical vein endothelium. Blood. 2002; 100:3597-3603. [PubMed: 12393634] 
41. Furuse M, Itoh M, Hirase T, Nagafuchi A, Yonemura S, Tsukita S. Direct association of occludin with ZO-1 and its possible involvement in the localization of occludin at tight junctions. J Cell Biol. 1994; 127:1617-1626. [PubMed: 7798316]

42. Hynes RO. Integrins: bidirectional, allosteric signaling machines. Cell. 2002; 110:673-687. [PubMed: 12297042]

43. Moreland JG, Fuhrman RM, Pruessner JA, Schwartz DA. CD11b and intercellular adhesion molecule-1 are involved in pulmonary neutrophil recruitment in lipopolysaccharide-induced airway disease. Am J Respir Cell Mol Biol. 2002; 27:474-480. [PubMed: 12356581]

44. Basit A, Reutershan J, Morris MA, Solga M, Rose CE Jr, Ley K. ICAM-1 and LFA-1 play critical roles in LPS-induced neutrophil recruitment into the alveolar space. Am J Physiol Lung Cell Mol Physiol. 2006; 291:L200-207. [PubMed: 16461431]

45. Rendu F, Brohard-Bohn B. The platelet release reaction: granules' constituents, secretion and functions. Platelets. 2001; 12:261-273. [PubMed: 11487378]

46. Zarbock A, Polanowska-Grabowska RK, Ley K. Platelet-neutrophil-interactions: linking hemostasis and inflammation. Blood Rev. 2007; 21:99-111. [PubMed: 16987572]

47. Ruggeri ZM. Von Willebrand factor. Curr Opin Hematol. 2003; 10:142-149. [PubMed: 12579041]

48. Yuan Y, Kulkarni S, Ulsemer P, Cranmer SL, Yap CL, Nesbitt WS, Harper I, Mistry N, Dopheide $\mathrm{SM}$, Hughan SC, et al. The von Willebrand factor-glycoprotein Ib/V/IX interaction induces actin polymerization and cytoskeletal reorganization in rolling platelets and glycoprotein $\mathrm{Ib} / \mathrm{V} / \mathrm{IX}$ transfected cells. J Biol Chem. 1999; 274:36241-36251. [PubMed: 10593912]

49. Gu M, Xi X, Englund GD, Berndt MC, Du X. Analysis of the roles of 14-3-3 in the platelet glycoprotein Ib-IX-mediated activation of integrin alpha(IIb)beta(3) using a reconstituted mammalian cell expression model. J Cell Biol. 1999; 147:1085-1096. [PubMed: 10579727]

50. Yap CL, Hughan SC, Cranmer SL, Nesbitt WS, Rooney MM, Giuliano S, Kulkarni S, Dopheide SM, Yuan Y, Salem HH, et al. Synergistic adhesive interactions and signaling mechanisms operating between platelet glycoprotein Ib/IX and integrin alpha IIbbeta 3. Studies in human platelets ans transfected Chinese hamster ovary cells. J Biol Chem. 2000; 275:41377-41388. [PubMed: 10967111]

51. Zaffran Y, Meyer SC, Negrescu E, Reddy KB, Fox JE. Signaling across the platelet adhesion receptor glycoprotein Ib-IX induces alpha IIbbeta 3 activation both in platelets and a transfected Chinese hamster ovary cell system. J Biol Chem. 2000; 275:16779-16787. [PubMed: 10828063]

52. Kroll MH, Hellums JD, McIntire LV, Schafer AI, Moake JL. Platelets and shear stress. Blood. 1996; 88:1525-1541. [PubMed: 8781407]

53. Ruggeri ZM. Mechanisms initiating platelet thrombus formation. Thromb Haemost. 1997; 78:611616. [PubMed: 9198225]

54. Andrews RK, Berndt MC. Adhesion-dependent signalling and the initiation of haemostasis and thrombosis. Histol Histopathol. 1998; 13:837-844. [PubMed: 9690140]

55. Romo GM, Dong JF, Schade AJ, Gardiner EE, Kansas GS, Li CQ, McIntire LV, Berndt MC, Lopez JA. The glycoprotein Ib-IX-V complex is a platelet counterreceptor for P-selectin. J Exp Med. 1999; 190:803-814. [PubMed: 10499919]

56. Andrews RK, Berndt MC. Platelet physiology and thrombosis. Thromb Res. 2004; 114:447-453. [PubMed: 15507277]

57. Luscher EF, Weber S. The formation of the haemostatic plug--a special case of platelet aggregation. An experiment and a survey of the literature. Thromb Haemost. 1993; 70:234-237. [PubMed: 8236124]

58. Bennett JS. Structure and function of the platelet integrin alphaIIbbeta3. J Clin Invest. 2005; 115:3363-3369. [PubMed: 16322781]

59. Savage B, Almus-Jacobs F, Ruggeri ZM. Specific synergy of multiple substrate-receptor interactions in platelet thrombus formation under flow. Cell. 1998; 94:657-666. [PubMed: 9741630]

60. Ruggeri ZM, Dent JA, Saldivar E. Contribution of distinct adhesive interactions to platelet aggregation in flowing blood. Blood. 1999; 94:172-178. [PubMed: 10381510] 
61. Yang J, Furie BC, Furie B. The biology of P-selectin glycoprotein ligand-1: its role as a selectin counterreceptor in leukocyte-endothelial and leukocyte-platelet interaction. Thromb Haemost. 1999; 81:1-7. [PubMed: 10348699]

62. Evangelista V, Manarini S, Sideri R, Rotondo S, Martelli N, Piccoli A, Totani L, Piccardoni P, Vestweber D, de Gaetano G, et al. Platelet/polymorphonuclear leukocyte interaction: P-selectin triggers protein-tyrosine phosphorylation-dependent CD11b/CD18 adhesion: role of PSGL-1 as a signaling molecule. Blood. 1999; 93:876-885. [PubMed: 9920836]

63. Ley K, Kansas GS. Selectins in T-cell recruitment to non-lymphoid tissues and sites of inflammation. Nat Rev Immunol. 2004; 4:325-335. [PubMed: 15122198]

64. Ramos CL, Smith MJ, Snapp KR, Kansas GS, Stickney GW, Ley K, Lawrence MB. Functional characterization of L-selectin ligands on human neutrophils and leukemia cell lines: evidence for mucinlike ligand activity distinct from P-selectin glycoprotein ligand-1. Blood. 1998; 91:10671075. [PubMed: 9446670]

65. Diacovo TG, Roth SJ, Buccola JM, Bainton DF, Springer TA. Neutrophil rolling, arrest, and transmigration across activated, surface-adherent platelets via sequential action of P-selectin and the beta 2-integrin CD11b/CD18. Blood. 1996; 88:146-157. [PubMed: 8704169]

66. Evangelista V, Manarini S, Rotondo S, Martelli N, Polischuk R, McGregor JL, de Gaetano G, Cerletti C. Platelet/polymorphonuclear leukocyte interaction in dynamic conditions: evidence of adhesion cascade and cross talk between P-selectin and the beta 2 integrin CD11b/CD18. Blood. 1996; 88:4183-4194. [PubMed: 8943853]

67. Simon DI, Chen Z, Xu H, Li CQ, Dong J, McIntire LV, Ballantyne CM, Zhang L, Furman MI, Berndt MC, et al. Platelet glycoprotein ibalpha is a counterreceptor for the leukocyte integrin Mac-1 (CD11b/CD18). J Exp Med. 2000; 192:193-204. [PubMed: 10899906]

68. Weber C, Springer TA. Neutrophil accumulation on activated, surface-adherent platelets in flow is mediated by interaction of Mac-1 with fibrinogen bound to alphaIIbbeta3 and stimulated by platelet-activating factor. J Clin Invest. 1997; 100:2085-2093. [PubMed: 9329974]

69. Diacovo TG, deFougerolles AR, Bainton DF, Springer TA. A functional integrin ligand on the surface of platelets: intercellular adhesion molecule-2. J Clin Invest. 1994; 94:1243-1251. [PubMed: 8083366]

70. Blanks JE, Moll T, Eytner R, Vestweber D. Stimulation of P-selectin glycoprotein ligand-1 on mouse neutrophils activates beta 2-integrin mediated cell attachment to ICAM-1. Eur J Immunol. 1998; 28:433-443. [PubMed: 9521050]

71. Urzainqui A, Serrador JM, Viedma F, Yanez-Mo M, Rodriguez A, Corbi AL, Alonso-Lebrero JL, Luque A, Deckert M, Vazquez J, et al. ITAM-based interaction of ERM proteins with Syk mediates signaling by the leukocyte adhesion receptor PSGL-1. Immunity. 2002; 17:401-412. [PubMed: 12387735]

72. Haselmayer P, Grosse-Hovest L, von Landenberg P, Schild H, Radsak MP. TREM-1 ligand expression on platelets enhances neutrophil activation. Blood. 2007; 110:1029-1035. [PubMed: 17452516]

73. Weyrich AS, McIntyre TM, McEver RP, Prescott SM, Zimmerman GA. Monocyte tethering by Pselectin regulates monocyte chemotactic protein-1 and tumor necrosis factor-alpha secretion. Signal integration and NF-kappa B translocation. J Clin Invest. 1995; 95:2297-2303. [PubMed: 7537762]

74. Evangelista V, Pamuklar Z, Piccoli A, Manarini S, Dell'elba G, Pecce R, Martelli N, Federico L, Rojas M, Berton G, et al. Src family kinases mediate neutrophil adhesion to adherent platelets. Blood. 2007; 109:2461-2469. [PubMed: 17095622]

75. Carvalho-Tavares J, Hickey MJ, Hutchison J, Michaud J, Sutcliffe IT, Kubes P. A role for platelets and endothelial selectins in tumor necrosis factor-alpha-induced leukocyte recruitment in the brain microvasculature. Circ Res. 2000; 87:1141-1148. [PubMed: 11110771]

76. Salter JW, Krieglstein CF, Issekutz AC, Granger DN. Platelets modulate ischemia/reperfusioninduced leukocyte recruitment in the mesenteric circulation. Am J Physiol Gastrointest Liver Physiol. 2001; 281:G1432-1439. [PubMed: 11705748]

77. O'Sullivan BP, Michelson AD. The inflammatory role of platelets in cystic fibrosis. Am J Respir Crit Care Med. 2006; 173:483-490. [PubMed: 16339920] 
78. Pitchford SC, Yano H, Lever R, Riffo-Vasquez Y, Ciferri S, Rose MJ, Giannini S, Momi S, Spina $\mathrm{D}, \mathrm{O}$ 'Connor B, et al. Platelets are essential for leukocyte recruitment in allergic inflammation. $\mathrm{J}$ Allergy Clin Immunol. 2003; 112:109-118. [PubMed: 12847487]

79. Zarbock A, Singbartl K, Ley K. Complete reversal of acid-induced acute lung injury by blocking of platelet-neutrophil aggregation. J Clin Invest. 2006; 116:3211-3219. [PubMed: 17143330]

80. Kiefmann R, Heckel K, Schenkat S, Dorger M, Wesierska-Gadek J, Goetz AE. Platelet-endothelial cell interaction in pulmonary micro-circulation: the role of PARS. Thromb Haemost. 2004; 91:761-770. [PubMed: 15045138]

81. Kiefmann R, Heckel K, Schenkat S, Dorger M, Goetz AE. Role of p-selectin in platelet sequestration in pulmonary capillaries during endotoxemia. J Vasc Res. 2006; 43:473-481. [PubMed: 16926551]

82. Belperio JA, Keane MP, Lynch JP 3rd, Strieter RM. The role of cytokines during the pathogenesis of ventilator-associated and ventilator-induced lung injury. Semin Respir Crit Care Med. 2006; 27:350-364. [PubMed: 16909369]

83. Andonegui G, Bonder CS, Green F, Mullaly SC, Zbytnuik L, Raharjo E, Kubes P. Endotheliumderived Toll-like receptor-4 is the key molecule in LPS-induced neutrophil sequestration into lungs. J Clin Invest. 2003; 111:1011-1020. [PubMed: 12671050]

84. Schulz C, Schafer A, Stolla M, Kerstan S, Lorenz M, von Bruhl ML, Schiemann M, Bauersachs J, Gloe T, Busch DH, et al. Chemokine fractalkine mediates leukocyte recruitment to inflammatory endothelial cells in flowing whole blood: a critical role for P-selectin expressed on activated platelets. Circulation. 2007; 116:764-773. [PubMed: 17679613]

85. Zhu J, Carman CV, Kim M, Shimaoka M, Springer TA, Luo BH. Requirement of \{alpha $\}$ and \{beta\} subunit transmembrane helix separation for integrin outside-in signaling. Blood. 2007

86. Marik PE. Aspiration pneumonitis and aspiration pneumonia. N Engl J Med. 2001; 344:665-671. [PubMed: 11228282] 


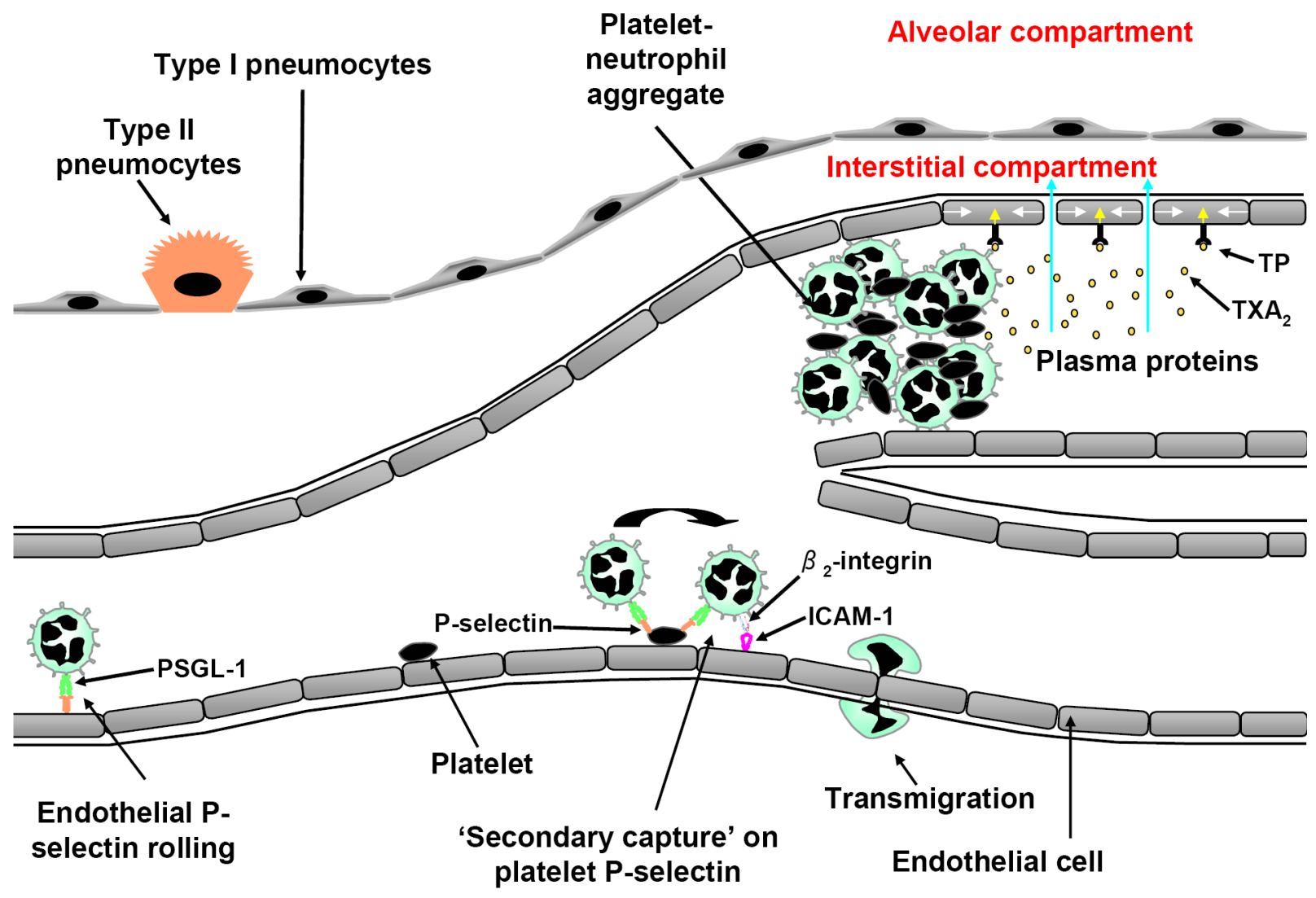

Figure 1. Role of platelets for neutrophil recruitment and regulation of vascular permeability in the lung

Neutrophils can roll on P-selectin expressed on endothelial cells (bottom left) and interact with platelets adherent to the endothelium (bottem center). This interaction is mediated by platelet P-selectin and PSGL-1 on neutrophils. This 'secondary capturing' might activate $\beta_{2}$ intregrins on neutrophils that subsequently can interact with ICAM-1 on endothelial cells (middle). Platelet-neutrophil aggregates (top right) lead to a reciprocal activation of the cells with a release of the lipid mediator thromboxane $\mathrm{A}_{2}\left(\mathrm{TXA}_{2}\right)$. $\mathrm{TXA}_{2}$ binds to thromboxane receptors (TP) expressed on endothelial cells. The activation of the receptors leads to an increase of vascular permeability with subsequent egression of fluid and plasma proteins from the intravascular into the interstitial and alveolar compartments. 


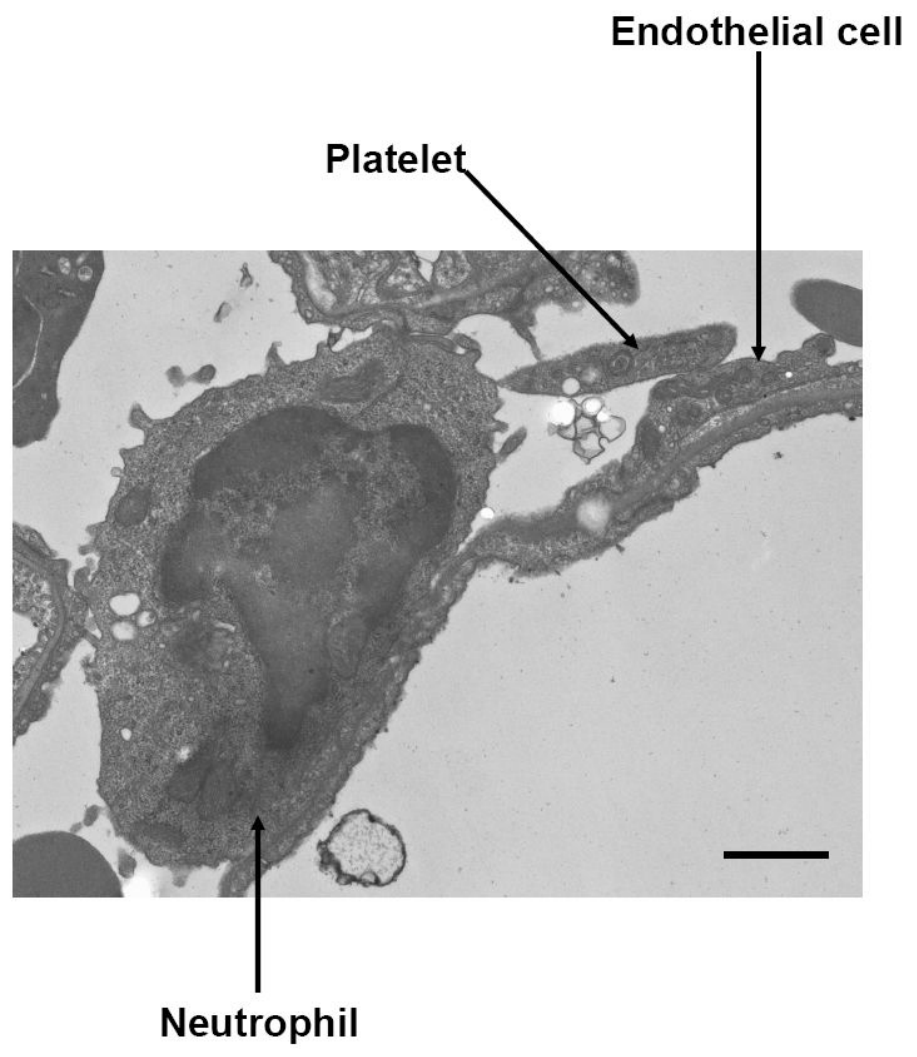

Figure 2. Platelet-neutrophil aggregate in the pulmonary microcirculation Platelet-neutrophil interaction 30 minutes after initiation of acid-induced ALI in pulmonary microvasculature visualized by electron microscopy. Platelet attached directly to the endothelium and a neutrophil. Scale bar: $1 \mu \mathrm{m}$. 